\title{
Acute Phase Protein Levels in Rats with Experimentally Induced Infectious and Noninfectious Inflammation
}

\author{
Mürüvvet Abbak ${ }^{1}$ and Pınar Alkım Ulutaş ${ }^{2 *}$ \\ ${ }^{1}$ Science Technology Research and Application Center, Adnan Menderes University Campus, Turkey \\ ${ }^{2}$ Department of Biochemistry, Adnan Menderes University, Turkey
}

Submission: September 09, 2017; Published: November 10, 2017

*Corresponding author: Pınar Alkım Ulutaş, Department of Biochemistry, Faculty of Veterinary Işıklı Neighborhood, Adnan Menderes University 09016 Efeler / Aydın, Turkey, Tel: 02562474700-263; Email: paulutas@adu.edu.tr

\begin{abstract}
In this study, it was investigated that the levels of acute phase proteins in rats with experimentally induced different inflammation models. In first groups rats were treated with $0.5 \mathrm{mg} / \mathrm{kg}$ turbentin oil (single dose, ip) for noninfectious inflammation. For infectious inflammation model, 21 rats that were in second group were treated by 106 Colony forming units (CFU) Staphylococcus aureus (ip). 21 rats in control group were given physiological saline in same way. Additionally, blood samples were collected to 7 healthy animals for 0 days. Days of 1, 4 ve 7, blood samples were collected intracardiac way in randomly selected 7 rats under ether anesthesia and applied euthanasia by cervical dislocation. Whole blood samples were used for fibrinogen analyses and blood counting; serum samples were analyzed C-reactive protein (CRP), Serum Amiloid A (SAA), haptoglobin in ELISA reader, ceruloplasmin, total protein and albumin analyses were measuring by spectrophotometric methods. As a result of this study, haptoglobin, fibrinogen and ceruloplasmin levels were significantly increased in rats with acute infectious and noninfectious inflammation group when compare between blood sampling days and in day 0. CRP and SAA levels were increased but were not determined any statistically significance. There were also observed that haptoglobin and fibrinogen concentrations were higher in infectious inflammation than noninfectious inflammation.
\end{abstract}

Keywords: Inflammation; Infectious; Noninfectious; Acute phase proteins; Rat; Acute phase protein levels in rats with experimentally induced infectious and noninfectious inflammation

\section{Introduction}

Acute phase response (APR) is an initial and immediate reactions against tissue damage, infection or physical trauma. During the APR, there is an increased synthesis of Acute Phase Proteins (APPs) which can be produced by hepatocytes and peripheral tissues [1]. At least 40 different plasma proteins have been identified as APPs. APPs are classified with respect to the direction of changes in the blood, that is, up regulated (positive) APPs and down regulated (negative) APPs and to the subset of primarily stimulating mediators [2]. The appearance of positive APPs is mainly caused by acting cytokines such as IL6 (Interleukin-6), IL1 (Interleukin-1), TNF (Tumor necrosis factor), TGF (Growth factor), IL8 (Interleukin-8) and IL-22 (Interleukin-22) [3-5].

CRP and SAA are widely used diagnostic and prognostic markers for different diseases, including cardiovascular risk [6], inflammatory bowel diseases [7] impaired lung function
[8], acute kidney injury as well as infectious diseases, severe inflammation, and sepsis [9]. CRP is one of the most frequently used markers of inflammation in humans and various animals, with the exception of ruminants [2]. In the rat CRP has been studied as a marker of inflammation using experimental models [10]. Haptoglobin is an important APP that increasing up to ten fold in the response of stimuli in humans and it has been also investigated as an indicator of inflammation in the rat [10]. Haptoglobin acts as a scavenger protein functioning to conserve hemoglobin iron released [11]. Fibrinogen is an important haemostatic factor and a major coagulation protein during the acute phase response occurring in traumas, inflammations or infections, fibrinogen concentrations in plasma rise rapidly [12].

Because of the APPS have showed differences in serum concentration during different phsiologic states, APPs attracted attention as potential biomarkers for use as diagnosis the diseases, monitoring the health condition and therapy [13]. Using of APPs 
as a marker of inflammation was depend on important factors such as magnitude of change in the circulation and reproducibility of the response inflammatory stimuli. Different inflammatory stimuli also affect the APR [10]. Making a distinction over the inflammation is important in terms of establishing the diagnosis of the disease, selecting and performing the effective treatment and preventing the complications to emerge in the long run. For this reason, in this study; in the infectious and non-infectious inflammation model experimentally induced in rats, the levels of CRP, SAA, haptoglobin, ceruloplasmin and fibrinogen, which are among acute phase proteins, were examined, and it was aimed that the applicability of these parameters in the distinction of inflammation be investigated.

\section{Material and Method}

\section{Animals}

A total of 70 female Wistar albino rats 3 month-old were used in this study. The mean weight of rats was 250-300g. This study was approved by the Institutional Animal Care and The Institutional Animal Ethics Committee of Adnan Menderes University, Turkey (Date: 01/03/2011, Number: 2011/18). Experiments were carried out in a semi-acclimatized room at $22{ }^{\circ} \mathrm{C}$, with $50-70 \%$ humidity and $12 / 12$-hour light/dark cycle. Rat was fed by standard rat feed and was allowed free access to water. Animals were acclimatized for at least 3 weeks before the experiment and were controlled for health status. Body weight was determined before the applications and at the end of the study. All experiments conformed of regulations with regard to animal care and use.

\section{Study Design}

Rats were randomized into three groups $(n=21)$ for applications and seven rats were divided for before application group (Day $0 ; n=7$ ).

a. Group 1: Infectious inflammation group $(\mathrm{n}=21)$ Staph. aureus was given by subcutaneous injection at $106 \mathrm{CFU} / \mathrm{mL}$.

b. Group 2: Non-infectious inflammation group $(n=21)$ $0.5 \mathrm{mg} / \mathrm{kg}$ turpentine oil (Riedel-de Haën, Germany) were administered by subcutaneous injection. c. Group3: The control group $(\mathrm{n}=21)$ received an equal volume of physiological saline $(0.7 \% \mathrm{NaCl})$ by subcutan way.

Day $0(n=7)$ : Before the applications, blood samples were collected in rats.

Blood samples were collected via hearth of randomly selected 7 rats from each application groups at 1, 4 and 7 days after Staphylococcus aureus, turpentine oil and physiologic saline injections. Blood samples were taken under the anaesthesia Serum was separated by centrifugation at $1700 \mathrm{~g}$ for $10 \mathrm{~min}$ and they were kept frozen $-20^{\circ} \mathrm{C}$ until analysis.

\section{Biochemical analyses}

CRP levels were measured using competitive enzyme immunoassay (AssayPro, Assay Max Rat CRP, USA). This assay employs a quantitative sandwich enzyme immunoassay technique that measures rat CRP. The final absorbance of the samples in a microplate reader at 450nm (Optic Ivyman System 2100C, Spain). The sample concentrations of CRP are determined by using the standard curve and multiply the value by the dilution factor. Haptoglobin and SAA levels were measured using a commercial test kits (Tridelta Development LTD, Ireland). The assays were performed by the manufacturer instructions using the microplate reader. Fibrinogen was measured the Millar Method [14]. Ceruloplasmin concentrations were measured spectrophotometrically as described by Sunderman \& Numato [15]. Total protein and albumin levels were measured using a automated clinical chemistry analyzer (Sinnowa D280, China). WBC levels were determined by using automatic blood counter (Abacus, Junior Vet, Diatron MI LTD, Hungary).

\section{Statistically analyses}

SPSS 11.5 package was used for all computations. All data were checked for normal distribution with Shapiro-Wilk and homogeneity of variance with Levene's test. If the data were not normally distributed, logarithmic or square root transformation was performed in order to normalize the distribution. Oneway analysis of variance (ANOVA) was conducted to assess the difference of groups. $\mathrm{P}$ values $<0.05$ were considered to be significant. The results were presented as the means \pm SE.

\section{Results}

Table 1: Mean serum CRP. SAA. Haptoglobin. ceruloplazmin. fibrinogen and WBC levels concentrations in rats.

\begin{tabular}{|c|c|c|c|c|c|c|}
\hline Parameters & Groups & $\begin{array}{l}\text { 0.Day } \\
\text { X } \pm \text { Se }\end{array}$ & $\begin{array}{l}\text { 1.Day } \\
\mathrm{X} \pm \text { Se }\end{array}$ & $\begin{array}{l}\text { 4.Day } \\
\mathrm{X} \pm \text { Se }\end{array}$ & $\begin{array}{l}\text { 7.Day } \\
\mathrm{X} \pm \text { Se }\end{array}$ & $\mathbf{P}$ \\
\hline \multirow{4}{*}{$\begin{array}{c}\text { CRP } \\
(\mu \mathrm{g} / \mathrm{ml})\end{array}$} & $\begin{array}{l}\text { Physiological } \\
\text { saline solution }\end{array}$ & \multirow{3}{*}{$2.59 \pm 0.66$} & $4.14 \pm 1.27$ & $4.37 \pm 1.12$ & $3.27 \pm 0.51$ & NS \\
\hline & Turpentine & & $3.32 \pm 0.54$ & $3.96 \pm 0.62$ & $4.58 \pm 1.54$ & NS \\
\hline & Staph.aureus & & $5.94 \pm 2.45$ & $2.93 \pm 0.19$ & $4.96 \pm 2.19$ & NS \\
\hline & $\mathrm{P}$ & NS & NS & NS & NS & \\
\hline $\begin{array}{c}\text { SAA } \\
(\mathrm{ng} / \mathrm{ml})\end{array}$ & $\begin{array}{l}\text { Physiological } \\
\text { saline solution }\end{array}$ & $3.80 \pm 0.45$ & $5.04 \pm 0.72$ & $4.71 \pm 0.84$ & $4.81 \pm 0.69$ & NS \\
\hline
\end{tabular}




\begin{tabular}{|c|c|c|c|c|c|c|}
\hline & Turpentine & & $5.34 \pm 0.78$ & $5.14 \pm 0.69$ & $5.07 \pm 0.91$ & NS \\
\hline & Staph.aureus & & $5.01 \pm 0.85$ & $5.14 \pm 0.69$ & $4.88 \pm 0.72$ & NS \\
\hline & $\mathrm{P}$ & NS & NS & NS & NS & \\
\hline \multirow{4}{*}{$\begin{array}{l}\text { Haptoglobin } \\
\qquad(\mathrm{g} / \mathrm{L})\end{array}$} & $\begin{array}{l}\text { Physiological } \\
\text { saline solution }\end{array}$ & \multirow{3}{*}{$0.84 \pm 0.08 \mathrm{~d}$} & $1.28 \pm 0.27 \mathrm{dc}$ & $1.32 \pm 0.26 \mathrm{dc}$ & $2.23 \pm 0.10 \mathrm{a}$ & $* * *$ \\
\hline & Turpentine & & $1.90 \pm 0.13 \mathrm{bc}$ & $1.35 \pm 0.22 \mathrm{~cd}$ & $2.41 \pm 0.23 \mathrm{a}$ & $* * *$ \\
\hline & Staph.aureus & & $2.10 \pm 0.2 \mathrm{ab}$ & $1.43 \pm 0.25 \mathrm{bcd}$ & $1.81 \pm 0.14 \mathrm{bc}$ & $* * *$ \\
\hline & $\mathrm{P}$ & NS & $* *$ & NS & $* * *$ & \\
\hline \multirow{4}{*}{$\begin{array}{l}\text { Ceruloplasmin } \\
\text { (mg/dl) }\end{array}$} & $\begin{array}{l}\text { Physiological } \\
\text { saline solution }\end{array}$ & \multirow{3}{*}{$26.51 \pm 1.78$} & $33.62 \pm 2.38 \mathrm{cde}$ & $42.32 \pm 3.36 \mathrm{bcB}$ & $26.88 \pm 1.21 \mathrm{eB}$ & $* * *$ \\
\hline & Turpentine & & $32.50 \pm 2.26 \mathrm{de}$ & $57.18 \pm 5.34 \mathrm{aA}$ & $42.42 \pm 3.36 \mathrm{bcA}$ & $* * *$ \\
\hline & Staph.aureus & & $32.12 \pm 3.20 \mathrm{de}$ & $45.60 \pm 3.98 \mathrm{bB}$ & $38.93 \pm 1.89 \mathrm{bcdA}$ & $* * *$ \\
\hline & $\mathrm{P}$ & NS & NS & $* * *$ & $* * *$ & \\
\hline \multirow{4}{*}{ Fibrinojen (mg/dl) } & $\begin{array}{l}\text { Physiological } \\
\text { saline solution }\end{array}$ & \multirow{3}{*}{$395.04 \pm 47.11$} & $450.13 \pm 51.42 \mathrm{C}$ & $390.84 \pm 39.28 \mathrm{~B}$ & $438.06 \pm 20.23 B$ & NS \\
\hline & Turpentine & & $680.96 \pm 85.69 \mathrm{bB}$ & $747.07 \pm 46.77 \mathrm{bA}$ & $616.96 \pm 54.92 \mathrm{bA}$ & $* * *$ \\
\hline & Staph.aureus & & $947.48 \pm 49.15 \mathrm{aA}$ & $734.48 \pm 53.33 \mathrm{bA}$ & $590.73 \pm 53.45 \mathrm{bcA}$ & $* * *$ \\
\hline & $\mathrm{P}$ & NS & $* * *$ & $* * *$ & $* *$ & \\
\hline \multirow{4}{*}{$\operatorname{WBC}\left(10^{3} / \mu \mathrm{l}\right)$} & $\begin{array}{l}\text { Physiological } \\
\text { saline solution }\end{array}$ & \multirow{3}{*}{$5.88 \pm 0.89$} & $6.43 \pm 0.84 \mathrm{bcA}$ & $4.69 \pm 0.61 \mathrm{cB}$ & $4.91 \pm 0.51 \mathrm{cB}$ & $* * *$ \\
\hline & Turpentine & & $2.58 \pm 0.56 \mathrm{~dB}$ & $5.55 \pm 0.89 \mathrm{cB}$ & $5.84 \pm 0.68 \mathrm{bcB}$ & $* * *$ \\
\hline & Staph.aureus & & $5.01 \pm 0.60 \mathrm{cA}$ & $8.02 \pm 0.47 \mathrm{bA}$ & $10.24 \pm 0.93 a A$ & *** \\
\hline & $\mathrm{P}$ & NS & $* *$ & $*$ & $* * *$ & \\
\hline
\end{tabular}

abc: Statistical difference between groups with different letters in the same line (day $0,1,4,7)$ is significant. $\left({ }^{* * *} p<0.001 ;{ }^{* *} p<0.01 ;{ }^{*} p<0.05 ; N S\right.$ : Not Significant)

ABC: Statistical difference between groups with different letters in the same column (Physiological saline solution. Turpentine. Staph. aureus Group) is significant. $\left({ }^{* * *} p<0.001 ;{ }^{* *} p<0.01 ;{ }^{*} p<0.05\right.$; NS: Not Significant)

The results of the mean serum AFP (CRP, SAA, haptoglobin, ceruloplasmin and fibrinogen) concentrations are shown in Table 1. Following the application, the AFP concentrations in turpentine and $S$. aureus groups showed a statistically significant increase on 1st, 4 th, and 7 th days when compared with 0 th day. Although the CRP and SAA levels showed an increase along with the application, no statistical difference could be determined.

The mean haptoglobin levels in Turpentine and $S$. aureus groups showed an increase in the wake of the application, and 1st day and 7th day-levels were found to be significantly high when compared with 0th day. When intergroup comparisons were made, 7 th day value in the Turpentine group $(\mathrm{p}<0.001)$ and 1 st day value in $S$. aureus group $(\mathrm{p}<0.01)$ were determined to be higher than the other groups.

The mean serum ceruloplasmin results, after the applications, escalated in each of the three groups, and the rate of increase was found to be statistically significant $(p<0,001)$. While the serum ceruloplasmin concentration dropped down to the normal level on 7th day in the physiological saline solution group, it coursed at a higher rate in the turpentine and $S$. aureus groups on 7 th day, as well. When intergroup comparisons were made, each of the three groups was observed to have given similar responses to the applications.
While, the blood fibrinogen levels in the turpentine and $S$. aureus groups showed statistically significant increases, no difference could be ascertained in the physiological saline solution group between 0 th, 1 st, 4 th and 7 th days. The tendency of the sharpest increase in this parameter was observed on 1st day in $S$. aureus group and on 4 th day in the turpentine group. It was observed that 7 th day-fibrinogen values in both of the groups had tended to decrease.

While the WBC values did not show any change in the physiological saline group, the post-application changes in the groups to which turpentine and $S$. aureus were applied were found to be statistically significant $(\mathrm{p}<0,001)$. The WBC level in the turpentine group was seen to have decreased on 1st day after the application; yet, an insignificant amount of escalation was determined on 4 th and 7 th days. In S. aureus group, on the other hand, the increase started on 1st day and then continued more and more later on, as well. While the WBC level made a peak on 7th day, a statistically significant difference was determined when physiological saline solution, turpentine and $S$. aureus groups were compared among themselves on all the days in question $(p<0,001)$. The highest WBC level was seen in the infectious inflammation group, $\mathrm{S}$. aureus. 
The results of the mean serum Total protein and albumin concentrations are shown in Table 2. While no difference could be determined in the total protein levels of the physiological saline solution group on 1st and 4th days when compared with the preapplication period, they were determined to have significantly decreased on 7th day. A significant level of decrease was seen in the turpentine and $S$. aureus groups on 4 th and 7 th days. The albumin level in the physiological saline solution group showed a decrease on 7 th day, whereas it was determined to have dropped down in the turpentine group on 4 th and 7 th days.

Table 2: Mean serum total protein and albumin concentrations in rats.

\begin{tabular}{|c|c|c|c|c|c|c|}
\hline Parameters & Groups & 0.Day X \pm Se & 1.Day $\mathrm{X} \pm$ Se & 4.Day X \pm Se & 7.Day X \pm Se & $\mathbf{P}$ \\
\hline \multirow{4}{*}{$\begin{array}{l}\text { Total Protein } \\
\qquad(\mathrm{mg} / \mathrm{dl})\end{array}$} & $\begin{array}{l}\text { Physiological } \\
\text { saline solution }\end{array}$ & \multirow{3}{*}{$8.75 \pm 0.13 a$} & $8.70 \pm 0.11 \mathrm{a}$ & $8.33 \pm 0.22 \mathrm{abcA}$ & $7.12 \pm 0.15 \mathrm{efB}$ & $* * *$ \\
\hline & Turpentine & & $8.71 \pm 0.15 a$ & $7.6 \pm 0.36 \mathrm{deB}$ & $6.95 \pm 0.19 \mathrm{fB}$ & $* * *$ \\
\hline & Staph.aureus & & $8.41 \pm 0.10 \mathrm{ab}$ & $7.80 \pm 0.09 \mathrm{cdB}$ & $7.82 \pm 0.21 \mathrm{bcdA}$ & $* * *$ \\
\hline & $\mathrm{p}$ & & NS & $* * *$ & $* * *$ & \\
\hline \multirow{5}{*}{$\begin{array}{l}\text { Albumin } \\
(\mathrm{mg} / \mathrm{dl})\end{array}$} & $\begin{array}{l}\text { Physiological } \\
\text { saline solution }\end{array}$ & \multirow{4}{*}{$5.20 \pm 0.13 a$} & $5.21 \pm 0.07 \mathrm{a}$ & $4.88 \pm 0.13 \mathrm{abAB}$ & $4.06 \pm 0.08 c \mathrm{c}$ & $* * *$ \\
\hline & & & & & & \\
\hline & Turpentine & & $5.14 \pm 0.06 a$ & $4.42 \pm 0.14 \mathrm{bcBC}$ & $4.34 \pm 0.09 \mathrm{bcBC}$ & $* * *$ \\
\hline & Staph.aureus & & $5.32 \pm 0.04 a$ & $5.53 \pm 0.67 \mathrm{aA}$ & $4.90 \pm 0.17 \mathrm{abA}$ & NS \\
\hline & $\mathrm{P}$ & & NS & $* * *$ & $* * *$ & \\
\hline
\end{tabular}

abc: Statistical difference between groups with different letters in the same line (day $0,1,4,7)$ is significant. $\left({ }^{* * *} p<0.001 ;{ }^{* *} p<0.01 ;{ }^{*} p<0.05\right.$; NS: Not Significant)

$A B C$ : Statistical difference between groups with different letters in the same column (Physiological saline solution. Turpentine. Staph. aureus Group) is significant.

$\left({ }^{* * *} p<0.001 ;{ }^{* *} p<0.01 ;{ }^{*} p<0.05 ;\right.$ NS: Not Significant $)$

\section{Discussion}

Haptoglobin level showed statistically significant increases after the application in all the groups, and the high level was observed on all the sampling days. In particular, it was seen that 1st day-level of the infectious group had proved to be higher than 1st day-level of the non-infectious group, and almost 3 times as much increase was seen to have taken shape, as well. Similarly, in a study conducted by Gilbertsen et al. [16] In which they created arthritis in rats, 5 times as much increase was determined on 14th day, whereas Giffen et al. [10] stated that there was an increase at peak level at 24th-36th hours (approximately 10 times as much) and that the high levels had continued throughout 21 days. Although no similar increase to that in other studies was seen, in our study, haptoglobin was determined to have shown a statistically significant increase, and it was concluded that the haptoglobin level had been affected more in the infectious inflammation model. The reason why there was less severe response was thought to be due to the severity of inflammation; the application way of inflammation-causing agents and the fact that haptoglobin in rats was an acute phase protein showing an increase on a moderate level.

In this study, even though the fibrinogen level in the physiological saline solution group did not change on any day when blood was taken, a significant level of increase was observed in the turpentine (non-infectious) and S. aureus (infectious) inflammation groups. 1st day level pertaining to the infectious inflammation group in particular showed almost 3 times as much increase when compared with the pre-application period, and the high level continued on all the days when blood was taken. These results show parallelism with those of Giffen et al. [10] and indeed, they reported in their study that the peak increase in the fibrinogen level had showed up at 24th hour. Similarly, Myers \& Fleck [17] in a model in which they created inflammation by applying subcutaneous turpentine, reported that the fibrinogen concentrations had increased twice as much at 18-20 hours after application. While Gardner et al. [18] reported that the fibrinogen levels in the rats on which acute lung damage was created increased twice as much 24 hours after the occurrence of inflammation, Larson et al. [19] stated that there was almost 4 times as much change after the application in the model in which experimental arthritis. Starting from all of these, it can be said that the differences in the increases seen in the fibrinogen levels are associated with the type and the severity of inflammation.

Ceruloplasmin is a copper-binding protein in the plasma. It functions as an antioxidant within the organism and inhibits the free oxygen radicals and lipid peroxidation $[20,21]$. In two experimental studies in which experimental liver damage and lung fibrosis $[22,23]$ were created in rats, it was reported that the ceruloplasmin levels had significantly increased when compared with those of the control group. Also in this study, the levels were $26.51 \pm 1.78 \mathrm{mg} / \mathrm{dl}$ prior to the application, whereas these levels were determined to have increased in all the groups after the 
application, and these values, except for the physiological saline solution group, were determined to have coursed at higher levels on all the days when blood was taken. It was ascertained in the physiological saline solution group that the ceruloplasmin level had dropped down to the initial level on 7th day. In terms of this parameter, no significant difference was found between the infectious and non-infectious groups. The severity and the duration of the increase in the ceruloplasmin levels are accordant with those in the other experimental models, which is also thought to be associated with the antioxidant characteristic of ceruloplasmin.

CRP is reported to be the major acute phase protein in humans and dogs $[11,13,20,24]$. The serum levels in those with normal liver functions are a good parameter indicating an inflammatory activity [24]. CRP synthesis and release are triggered by IL-1, IL-6 and TNF- $\alpha[11,25]$. It was reported that CRP in rats was not the primary major acute phase protein and that its level under basal conditions proved to be higher when compared with human CRP $[26,27]$. However, in many experimental studies conducted, the rat CRP was stated to be used as the inflammation indicator, indicating to an inflammation [28-30]. In this study, following the impulses/signals, it was determined to have showed an increase after the application in all of the three test groups; yet, it was ascertained that there was no statistical significance in the inter-day-comparisons of CRP levels. Nonetheless, the level was $2, .9 \pm 0.66 \mu \mathrm{g} / \mathrm{ml}$ in the control group of rats prior to the application, whereas 1st day level in S. aures (infectious inflammation) group was observed to have escalated up to mean $5.94 \pm 2.45 \mu \mathrm{g} / \mathrm{ml}$ and dropped down once again later on. In the turpentine group, however, a CRP level that increased day by day was determined. In a study conducted by Connolly et al. [31] in which arthritis was created by administering an adjuvant, it was reported that the CRP level had increased by $138 \%$ on 17 th day, whereas Bürger et al. [32] stated that the increases in CRP levels had been observed on 4 th and 15 th days. In this study, the CRP level showed twice as much increase on 1 st day in only $S$. aureus (infectious inflammation) group, while no increase could be determined on other days and in other groups.

It is reported that the SAA concentration in the cases of inflammation in dogs, humans, rats, cats, cattle and rabbits had increased prominently and that this increase could be used in determining inflammatory conditions in the early stage [33]. In this study, even though an increase in the levels was seen on 1st days following the application in all the groups, this change was found to be statistically insignificant. It can be said that the reason for this could be associated with the severity and the location of inflammation, as in CRP. In a study conducted by Sultan et al. [34], in which sterile abscess was created through turbentine, it was reported that the liver expressions of SAA had increased twice as much. Yet, it was also stated that more dramatic increases in rats had been seen in different acute phase proteins [34].
In the cases of acute inflammatory conditions, the synthesis of acute phases proteins from the liver increases, whereas the albumin synthesis decreases [35]. In this study, it was observed that there was a decrease in the albumin concentration after the application in the turpentine group on 4th day and in S. aureus group on 7th day. Similarly, it was ascertained that there was also a decrease in the total protein levels on 4 th and 7 th days in the turpentine and $S$. aureus groups. The decrease determined in albumin concentrations indicate to a negative acute phase response [24] 30-60\% decrease is determined in the course of the acute phase reaction in humans, whereas Connolly et al. [31] determined $47 \%$ decrease in the rats in their arthritis model, and Lioa et al. [36] determined $45 \%$ decrease in an experiment in which inflammation was created through -the administration of subcutaneous turpentine. In a research carried out by Giffen et al. [24], in which acute inflammation was created by administering IP adjuvant, a 57\%-decrease was determined on 3rd and 7th days after the application. The results of this study are also accordant with those of similar studies, and these results suggest that a decrease occurs in the hepatic synthesis of albumin along with the occurrence of inflammation and that it acts as a negative acute phase protein, as well. It was though that the reason for the decline that was seen in the total protein levels had occurred in parallel to the decrease in albumin, and it was also considered that the increase in the globulin fraction had occurred as the result of not having much effect on the total protein levels.

Leukocytosis is one of the typical findings of inflammatory changes, and it is the primary one of the most sensitive responses to IL-1 [37]. Following the acute inflammation, the increase in the number of leucocytes in the short term mainly results from delivering cells from the neutrophile pool into the circulation and also due to the increase in the number of the band neutrophiles within the circulation as the result of granulopoiesis that is stimulated later on. In this study, it was determined that the number of WBC had decreased on 1st day in the turpentine group and increased afterwards. It was thought that the reason for this was associated with the migration of the neutrophiles within the circulation from the periphery towards the inflammation focus as well as the decrease of their levels within the circulatory blood. It was concluded that the clinical picture of leukocytosis on 4th and 7th days in the turpentine group and on 1st, 4th and 7 th days in $S$. aureus group consisted of a specific inflammatory response that showed up in the wake of acute inflammation. It was also concluded that the most prominent increase in the number of leucocytes had occurred on 7th day in S. aureus group, which resulted from the fact that the infectious inflammatory model had posed a more prominent and systemic response.

As a result of this study, APP analyses can be used for diagnose and monitor to infectious and noninfectious inflammation. In addition, results of this study can be used as reference in future studies. We have shown that haptoglobin, fibrinogen 
and ceruloplasmin higher in infectious and noninfectious inflammation in rat than CRP and SAA. In addition, we conclude that haptoglobin and fibrinogen proved to be a sensitive indicator of acute infectious and non-infectious inflammation. However, there is a need to be future study that determine to severity of inflammation as histopathologically.

\section{Acknowledgement}

This study was carried out by Adnan Menderes University Scientific Research Projects Unit by; VTF-12029 and 'Experimental Infectious and Non-Infectious Inflammation Comparison of Some Acute Phase Protein Levels in Rats Created Supported by the Project and this article has been written using the first author's master thesis

\section{References}

1. Schmidt EMS, Eckersall PD (2015) Acute phase proteins as markers of infectious diseases in small animals. Acta Veterinaria 65(2): 149-161.

2. Schrödl W, Büchler R, Wendler S, Reinhold P, Muckova P (2016) Acute phase proteins as promising biomarkers: Perspectives and limitations for human and veterinary medicine. Proteomics Clin Appl 10(11): 1077-1091.

3. Tilg H, Dinarello CA, Mier JW (1997) IL-6 and APPs: anti-inflammatory and immunosuppressive mediators. Immunol Today 18(9): 428-432.

4. Gabay C, Kushner I (1999) Acute-phase proteins and other systemic responses to inflammation. New England Journal of Medicine 340: 448-454.

5. Liang SC, Nickerson NC, Pittman DD, Carrier Y, et al. (2010) IL-22 induces an acute-phase response. The Journal of Immunology 185(9): 5531-5538.

6. Salazar JM, Martinez S, Chavez M, Toledo A (2014) C-reactive protein: clinical and epidemiological perspectives. Cardiology Research and Practice.

7. Magro F, Sousa P, Ministro P (2014) C-reactive protein in Crohn's disease: how informative is it? Expert Review of Gastroenterology Hepatology 8(4): 393-408.

8. Agassandian M, Shurin GV, Ma Y, Shurin MR (2014) C-reactive protein and lung diseases. Int J Biochem Cell Biol 53: 77-88.

9. Eckersall PD, Bell R (2010) Acute phase proteins: biomarkers of infection and inflammation in veterinary medicine. Veterinary Journal 185(1): 23-27.

10. Giffen PS, Turton J, Andrews CM, Barrett P, Clarke CJ, Fung et al. (2003) Markers of experimental acute inflammation in the Wistar Han rat with particular reference to haptoglobin and C-reactive protein. Archives of Toxicology 77(7): 392-402.

11. Ceron JJ, Eckersall PD, Martinez SS (2005) Acute phase proteins in dogs and cats: current knowledge and future perspectives. Veterinary Clinical Pathology 34(2): 85-99.

12. Manten GTR, Franx A, Sıkema JM, Hameetman TM, Gerard HA, et al (2004) Fibrinogen and high molecular weight fibrinogen during and after normal pregnancy. Thrombosis Research 114(1): 19-23.

13. Eckersall PD, Bell R (2010) Acute phase proteins: Biomarkers of infection and inflammation in veterinary medicine. The Veterinary Journal 185(1): 23-27.

14. Benjamin MM (1979) Fibrinogen Outline of Veterinary Clinical Pathology, The Lowa State University Pres, Ames, Iowa, USA.
15. Sunderman FW, Numato S (1970) Measurement of human serum ceruloplasmin by its p-phenylene diamine oxidase activity. Clinical Chemistry 16(11): 903-910.

16. Gilbertsen RB (1986) Rat haptoglobin: method of quantification and response to anti arthritic therapy in collagen arthritis. Immuno pharmacology 11: 69-77

17. Myers MA, Fleck A (1988) Observations on the delay in onset of the acute phase protein response. British Journal of Experimental Pathology 69(2): 169-176.

18. Gardner SY, Lehmann JR, Costa DL (2000) Oil fly ash-induced elevation of plasma fibrinogen in rats. Toxicological Sciences 56(1):175-180.

19. Larsson A, Bjork J, Lundberg C (1997) Nephelometric determination of rat fibrinogen as a marker of inflammatory response. Veterinary Immunology and Immunopathology 59(1-2): 163-169.

20. Gruys E, Oblowo MJ Toussaint JM (1994) Diagnosis significance of major acute phase proteins in veterinary clinical chemistry: a review Veterinary Bulletin (64)11: 1009 - 1015.

21. Ulutas PA, Ozpinar A (2006) Effect of Mannheimia (Pasteurella) haemolytica infection on acute-phase proteins and some mineral levels in colostrum-breast milk-fed or colostrum-breast milk-deprived sheep. Veterinar Research Communucations 30(5): 485-95.

22. Ertekin A (1996) Karbontetraklorür ile Deneysel Siroz Oluşturulan Tavşanlarda Sialik Asit, Lipit Bağlı Sialik Asit, Total Protein ve Bazı Spesifik Karaciğer Enzimlerinin Aktivitelerinin Araştırılması. Doktora Tezi. Yüzüncü Yıl Üniversitesi, Sağlık Bilimleri Enstitüsü, Van.

23. Çelikezen ÇF, Ertekin A (2008) Investigation of the Levels of Lipid Peroxidation (MDA), Antioxidant Substances (Glutathione, Ceruloplasmin) and Antioxidant Vitamins ( $\beta$-carotene and Retinol) in the Experimental Pulmoner Fibrosis in Rats, Yüzüncü Yll Üniversitesi Veteriner Fakültesi Dergisi 19(2): 17-20.

24. Gruys E, Toussaint MJ, Niewold TA, Koopmans SJ (2005) Acute phase reaction and acute phase proteins. J Zhejiang Univ Sci B 6(11): 10451056.

25. Nunomura W, Takakuwa Y, Higashi T (1994) Changes in serum concentration and mRNA level of rat CRP. Biochimica et Biophysica Acta (BBA). Molecular Basis of Disease 1227: 55-70.

26. Diaz PN, Bleeker WK, Lubbers Y, Rigter GM, Van Mierlo GJ et al. (2003) Rat CRP activates the autologous complement system. Immunology 109(4): 564-571.

27. Faddah LM, Abdel Baky NA, Al-Rasheed NM, Al-Rasheed NM, Fatani A] (2010) Role of Quercetin and orjinin in amelioriating nano zinc oxide induced nephrotoxicity in rats. BMC Complemantery and Alternative Medicine 12: 60 .

28. Atli M, Erikoglu M, Kaynak A, Esen HH, Kurban S (2012) The effects of selenium and vitamin $\mathrm{E}$ on lung tissue in rats with sepsis. Clinical Investigative Medicine 35(2): E48-54.

29. Kahyaoğlu A (2011) Deneysel diabet oluşturulan ratlarda bazı akut faz proteinleri ve iz elementler arasındaki ilişkiler. Yüksek Lisans Tezi, Adnan Menderes Üniversitesi, Sağlık Bilimleri.

30. Connolly KM, Stecher VJ, Kent L (1988) Examination of interleukin-1 activity, the acute phase response, and leukocyte subpopulations in rats with adjuvant-induced arthritis. Journal Laboratory Clinical Medicine 111(3): 341-347.

31. Bürger W, Schade R, Hirschelmann R (1987) The rat C-reactive protein-isolation and response to experimental inflammation and tissue damage. Agents Actions 21(1-2): 93-97.

32. Petersen HH, Nielsen JP, Heegaard PM (2004) Application of acute phase protein measurements in veterinary clinical chemistry. Veterinary Research 35(2): 163-187. 
33. Sultan S, Pascucci M, Ahmad S, Malik IA, Bianchi A (2012) Lipocalin-2 is a major acute-phase protein in a rat and mouse model of sterile abscess. Shock 37(2): 191-196.

34. Feldman BF, Zinkl JGJ (2000) Overview of plasma proteins, In: Schalm's Veterinary Hematology. NC Inc. Lippincott Williams \& Wilkins, Philadelphia.

35. Liao WS, Jefferson LS, Taylor JM (1986) Changes in plasma albumin concentration, synthetic rate, and mRNA level during acute inflammation. American Journal of Physiology 251(6): C928-C934.

36. Dinarello CA (1989) İnterleukin-1 and its biologically related cytokines. Advances in Immunology 44: 153-205.

37. Jain NC (1993) Essentials of Veterinary Hematology. Lea \& Febiger records, Philadelphia.
This work is licensed under Creative Commons Attribution 4.0 Licens DOI: 10.19080/JDVS.2017.04.555642

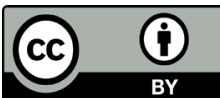

\section{Your next submission with Juniper Publishers will reach you the below assets}

- Quality Editorial service

- Swift Peer Review

- Reprints availability

- E-prints Service

- Manuscript Podcast for convenient understanding

- Global attainment for your research

- Manuscript accessibility in different formats

( Pdf, E-pub, Full Text, Audio)

- Unceasing customer service

Track the below URL for one-step submission https://juniperpublishers.com/online-submission.php 